\title{
ANTICIPATION SKILL-A CHALLENGE OF THE 21ST CENTURY GENERATIONS
}

\author{
Viorelia LUNGU \\ Associate Professor at the Technical University of Moldova, Republic of Moldova \\ DOI: 10.46609/IJSSER.2020.v05i08.013 URL: https://doi.org/10.46609/IJSSER.2020.v05i08.013
}

\begin{abstract}
Both the society and personality are developing and changing under the influence of education. Whilst the accelerated pace of changes as well as the current issues of the society, confirm the challenges which the 21 st century generations are subjected to, where the need to develop a skill of anticipation is claimed.

In this regard, some states give a special emphasis to anticipating skills, as a political objective to create a system for skill development required on the labour market. The anticipation skill represents a necessity of the modern personality to identify specific and rapid solutions in solving the multiple problems that appear in the 21 st century, to orient towards the planning of the change or the possibility to adapt.

An effective anticipation and matching of skills, based on the data related to the labour market and quality, may interfere with education, vocational training and employment in order to prepare the 21 st century generations to face the challenges.
\end{abstract}

Key words: anticipation, skill, prognosis, predictions, etc.

\section{Introduction}

It is important to understand that "in order to change and develop science and culture, technique and technologies, economics, politics and human spirituality it is necessary to change and develop the consciousness and behaviour of the personality. In the postindustrial age, the change and development of society accelerated and became almost uncontrollable. It endangers the global destiny of humanity"(Panico, Gubin \& Munteanu, 2011, p. 13).

The reality shows that solving the problems faced by education and training, but also clarifying the impact of education on shaping the future, requires prospective studies, which would offer 


\section{International Journal of Social Science and Economic Research}

ISSN: $2455-8834$

Volume:05, Issue:08 "August 2020"

alternatives and solutions for practically efficient actions i.e. initiating change in time, thus focusing on a new way of understanding the change.

Today, the humanity can no longer expect spontaneous and accidental changes, which lead to a multitude of psychological, economic crises, it needs to anticipate the challenge and plan changes as well.

Both anticipation and planning foresee an end point of an act by preparing for future action planning, based on data, detailed needs analysis and consultation with interested parties.

Anticipation is the beginning phase of planning in the decision-making process regarding: What should be done? When should it be done? Where should it be done? Who should it be done by? How should it be done? What resources are to be used? Or in other words, at the stage of establishing the premises regarding the future conditions, the factors that could create problems in the attempt to reach the objectives are to be identified.

In the second half of the 20th century G. Berger stated that the future could be foreseen in its broad lines, it could be projected within certain limits and therefore it is necessary to develop an educational system, conceived from the perspective of this future (apud. Barbaros, 2018), thus confirming the need for a skill called anticipatory.

In general, in the literature, is insufficient mentioned about the competence of anticipation. Therefore, in the present research we focused both on the conceptual delimitation of anticipation as a term, but also to highlight the essence and importance of this competence for the person or generation of the 21st century. On the one hand, everything changes quickly, sometimes chaotically and on the other hand, both the young specialist and the experienced one, are put in the situation to adapt to these changes.It is time to grasp that it is much more necessary to anticipate these changes than to plan them, or we risk being caught in the chaotic tumult of changes.

The research focused on the hypothesis: students from the Technical University identify solutions to adapt to changes that may be in their specialty, thus highlighting the presence of elements of anticipation competence.

As objectives, we set ourselves:

- analysis of the literature with reference to anticipation, anticipation of skills for the labor market;

- anticipation of specialities in the future;

- determination of actions of students from IT, leading to an appropriate adaptation to social changes.

The Republic of Moldova is at the inception, both in anticipating the necessary competencies for the labor market, and the fact that a special course on change management, or on anticipatory competence, has not been taught in the university.It is very important to put a special emphasis on the formation of the anticipatory competence. 


\section{International Journal of Social Science and Economic Research}

ISSN: $2455-8834$

Volume:05, Issue:08 "August 2020"

Therefore, the research will lead to the systematization of the meanings of the concept of anticipation, to the establishment of its functions. But we will also determine whether IT students will identify the actions needed to adapt to change.

The ability to anticipate the social or actual life of the personality, of different generations is described as an anticipatory character.

\section{Conceptual delimitations and anticipation functions}

Anticipation means the ability of the system, in one way or another, to predict the evolution of different events, results of actions, phenomena. (Dex online)

In the science of psychology, two aspects of these concepts are distinguished: the ability of an individual to imagine the likely outcome of an action before it is completed, and the thinking ability of an individual to imagine a possible means of solving a problem before its actual solving. The ability of one's organism to prepare to respond to different events before they occur (Anticipation, 2019).

Anticipation is a special phenomenon of "throwing forward", a projection, that is, an anticipatory reflection, which may provide the subject with an opportunity to "look into the future".

B.F. Lomov claimed that "reflecting forward" can occur in the form of foreseeing (extrapolation, foreseeing, anticipation) and setting goals. The setting of goals is what determines the reflecting forward, which is included in the activity of the individual. The objective acts as a reflection before the future result of such an activity. Anticipation is considered to be a guiding reflection of the real course of variousgivencircumstances but disregarding the individual (apud. Townsend, 2012).

The concept of anticipation combines manifestations of mental abilities with anticipatory reflection. In a broad sense, the anticipation is the ability to act and make various decisions, with a certain space-time, regarding the expected future events (Anticipation, 2019).

The anticipation has the function of regulation, cognition and communication.

The regulatory function is manifested by limiting the levels of freedom of the system according to the temporal-spatial structure of the environment. The regulation of the activity cannot take place without building a model of the desired future or of an acceptor of the action-based result, which makes it possible to compare the achieved action-based results to the parameters of the desired result. The anticipation process guarantees this aspect of regulation, because the result is a future event in connection with the act. The results of the anticipation are included in the decision as being its necessary and essential components. Therefore, the role of the anticipation process in regulating the activity and behaviour of the individual is highly important.

The anticipation participates in the selection of information in the processes of memorization and perception. In this regard, B. F. Lomovstated that the process of memorization is not a 


\section{International Journal of Social Science and Economic Research}

ISSN: $2455-8834$

Volume:05, Issue:08 "August 2020"

mechanical record of what affects an individual at a certain time, due to the need to involve the selection of perceived information. The leading role in the process of collecting information for the memory process has plans and predictions, built by the individual in the process of his behaviour (apud. Anticipation, 2019).

The prognosis is included in almost all cognitive processes, therefore, the anticipation is considered to be a transversal mental process (Anticipation, 2019).

The mechanism of memory can set the mechanisms of anticipation in motion i.e foreseeing and prediction.

A. Tarnovschi and J. Racu state that the representation is manifested in the aspect of anticipated mental preparation of actions, in the plan and the program of the actions directed towards the external objects and situations, the image representing a compulsory link, which is realized in the form of representation. It will include the chaining scheme of the sequence of the actions and the corresponding information on the mid-object (instrument), on the target-object (which is to be achieved by acting) and on the spatial-temporal coordinates of the context (environment) in which the action takes place. The clarity and completeness of the image determines the internal consistency of the program and the plan (Tarnovschi \& Racu, 2017, p.55).

There is also an anticipatory, indissoluble internal imagination related to the composition of each individual activity. Under the conditions of insufficient stimulation by one of the interchangeable mechanisms, the activation of imagination occurs. From the previously collected information there are an infinite number of new combinations, which are caused by the active areas of our subconscious, with a thematic focus on the perception of present moment.

Gelllerstein designated manifestations of the processes of anticipation of the actions of other individuals, which are based on the conscious (or not always conscious) awareness of the emotions of logic and the activity to which they lead (apud. Anticipation, 2019).

At the same time, based on thinking, says A. Tarnovschi, J. Racu, an individual can mentally anticipate the development of certain events and plan future actions accordingly. Through the contribution it brings to the knowledge of reality, thinking gives the human behaviour the trait of rationality (Tarnovschi \& Racu, 2017, p.97). Further, the researchers argue the anticipation as a mental process through the analysis of thinking on the temporal axis that is realized between the past, present and future. The sensory processes, especially sensation and perception, are being performed "here and now", at present. The thinking process, on the other hand, extracts its contents, to the largest extent, from memory, from the past; updates them, in relation to the requirements of the present, information, knowledge and experiences, this way making anticipations and predictions about the future (P. Popescu-Neveanu). The anticipatory approach of thinking also refers to the subject's orientations, their action plans. With the help of thinking, we plan our future and organize our existence (apud. Tarnovschi and Racu, 2017, p.98). 


\section{International Journal of Social Science and Economic Research}

ISSN: $2455-8834$

Volume:05, Issue:08 "August 2020"

According to Dm. Fadeev, the anticipation in activity captures the following aspects of the development of situations: transformation of conditions, probable options for the construction of executive acts, variations in the assessment of probable results, in order to adjust the model circumstances and the program of executive acts (apud. Anticipation, 2019).

The communication function of anticipation is observed whenever we consider major objectives: (Stânea, p.9).

- to be received;

- to be understood;

- to be accepted;

- to provoke a reaction, consisting of behavioural or attitude change.

Any linguistic statement is a triple sign, and the act of signifying is oriented in three directions:

- towards the communicated content (the representation function)

- towards the recipient targeted by the content (call function)

- towards the speaker (expression function).

Communication has transformative functions that allow anticipation of the finality even from the initial phase when objections are anticipated and formulatedbefore the interlocutor did it.

In the explanatory dictionaries the terms prognosis (Dex online, prediction, 2019), foreseeing andprediction (Godet, 1994) are suggested as beingsynonymical to anticipation.

T. Stefanovskaya states that prognosis as a function of pedagogical monitoring, ends the learning-diagnosis-prognosis cycle. However, in practical activities this structure is reversed, the prognosis being often the initial stage (anticipation of the action), because the productivity of the pedagogical process is determined by the goal (Stefanovskaya, 1998, p.263).

In this context, the author M. Stanciu also sustains that the anticipation from a scientific perspective is inscribed as an existential necessity of the modern individual. This forwardlooking vision enables people to face complex problems raised by daily activity, in a world that has emphasized its interdependencies, mobility, as well as the speed of process and phenomenom development (Stanciu, 1999, p.15).

Anticipation is directly related to personality traits. A direct correlation will be the connection of the predicting skill with the personal traits that ensure the success of the adaptation processes (sociability, emergence, change). Whilst the connection of such skill with personal traits that are responsible for the instability of the mental sphere (depression, neuroticism, aggression, lability) will be reversed. Thus, undeveloped anticipation mechanisms may indicate possible disorders in the mental system of the individual (Anticipation, 2019), of a generation.

The much discussed "know how" becomes the key phrase of present and future learning.

The above stated, confirm the idea of the Russian pedagogue G. Vorobiev who believes that the concept of anticipating in pedagogy does not just mean solving the problem of how to learn, but also what for? Who for? Where? With the help of what? (Vorobiev 1991, p. 8). 


\section{International Journal of Social Science and Economic Research}

ISSN: $2455-8834$

Volume:05, Issue:08 "August 2020"

In this aspect, a modern and relevant national curriculum for the present and future can only be achieved through a serious paradigm shift. It is about the urgent need for a national curriculum to be adjusted to the latest international trends in the socio-economic and educational field, focused on ensuring the relevance of the studies for the personal, social and professional development of the learner (Gremalschi, 2015, p.10) according to the challenges imposed by the society.

Planning is a decision-making process where we analyze the present (the current situation), define the desired future (where we want to reach) and find the solutions to get there. The planning process is defined by: the time periods which it refersto; the degree of specificity, details and clarity that describe thepresent, future and solutions (Vasilache and Bunyan, 2019, p.12).

This process begins with defining the long-term future called vision and continues with identifying the short-term future i.e the specific objectives, which will help the generation, involved in the learning process, to reach their visionstep-by-step (Văideanu, 1988, p.33)

To know, to be able and to be motivated to anticipate the educational action, in a disciplined and optimistic way, with a positive and mobilising focus, at the level of educational micro-, mesoand macrostructure become educational purposes.

By definition, any objective anticipates a reality that does not yet exist, foreshadows a capacity that is to be formed. Ever since the academic staff, by virtue of their own professional demands, have made such anticipations by elaborating and ordering the goals of the instructionaleducatitional activities with the beneficiaries.

However, the design of objectives can be achieved at different levels of generality and rigour, indicating the human capabilities and performances in a more abstract or concrete way. The issue is of high importance, because as noted by G. A. Landsheere "the modern theory of program development, programmed education, the theory of formative and summative assessment, education planning, they all rely on the indispensable precision required for the objectives to be pursued, without which all these initiatives are inevitably doomed to failure" (Landsheere, 1979, p. 11).

It is important to mention, however, that J. Botkin, qualifies anticipation as a finality, i.e. a skill, stating that anticipation is the ability to cope with new situations, eventually never encountered before, is the cornerstone of innovative learning processes. Anticipation is the ability to forsee the future, the upcoming events and the mid-term and long-term consequences of decisions and actions (Botchin, Elmangjra and Malita, 1981, p.46), thus developing certain personality traits.

\section{Skill anticipation at an international level}

Anticipating the needs for certain skills is directly influenced by technology, climate and demographic changes. People would reap considerable benefits if they knew the type of education and vocational training they would be pursuing. Companies would know the skills 


\section{International Journal of Social Science and Economic Research}

ISSN: $2455-8834$

Volume:05, Issue:08 "August 2020"

they need, and decision makers could adjust the education and vocational training systems to new skill needs.

By developing the anticipation skill, we analyze how the labour market develops and, consequently, the activity in the workplace, because both skills and the learning needs are changing.

Anticipation and effective skill matching, based on the data on the labour market and high quality skills, requires "uniting" education, vocational training and employment.

On the Electronic Platform for Adult Education in Europe (EPALE) it is highlighted that it would be useful to know how the labour market will be transformed by technology, climate and demographic changes. Individuals would benefit greatly if they knew the type of education and vocational training they would take up. Also, the companies would know the skills they need, and the decision makers could adjust the education and training systems to the new skill needs (Angeluta, 2017).

On the same Platform, it is stipulated that the Member States of the European Union use the skill anticipation at anational and regional level to support policies related to employment, education and vocational training. As an example, the economic policy in Latvia and the transition to a greener and digital economy in Ireland. Government agencies and public employment services are not the only ones who apply skill anticipation. For example, in Germany, France and Austria, the social partners use the skill anticipation to inform the decision-making process at depertamental or enterprise level (Angheluta, 2017).

In the same document, it is emphasized that, the approach of the methods of anticipation of skills varies throughout the European Union; the most important are skill assessments, prognoses and predictions (Angheluta, 2017).

Some methods are better for describing the current state of supply and demand for skills; others to provide long-term projections.

All Member States, except the Czech Republic, Cyprus and Hungary, use qualification assessments or qualification audits at national and / or, as in Sweden, at regional level. These can provide a comprehensive analysis of current qualification needs and the possible implications of past trends in the future. Sometimes the focus falls on sectors, such as the labour market monitoring system in Estonia and the future skill prediction (Angheluta, 2017).

Many Member States use the quantitative aptitude prognosis. These are usually based on economic models that make assumptions about many factors that influence the labour market to estimate future developments in the sectors, for occupations and skills. To be effective, the quantitative aptitude prognosis needs high quality data on the labour market, with longtermseries.

Other approaches to anticipating skills include studies of employers and employees and followup studies of graduates of vocational education and training programs. In this respect, the 


\section{International Journal of Social Science and Economic Research}

ISSN: $2455-8834$

Volume:05, Issue:08 "August 2020"

Netherlands monitors the transition to work of graduates from most components of the educational system (Angheluta, 2017).

In general, Member States consider that by improving the alignment of the skill supply and demand in order to reduce skill discrepancies is an objective of their approach to anticipating skills.

In the United Kingdom, for example, the skill anticipation is part of a policy objective of creating a market-like training and skills system. Employers and educational beneficiaries use the information they need to decide on the skills they need. These decisions are transposed into demand, which the market welcomes by improving the supply (Angheluta, 2017).

While EU countries invest in their capacity for skills anticipation and adjustment, finding solutions to current and future challenges requires a deeper and more focused analysis. The complexity of anticipating skills makes it necessary to explore country examples to find important answers, as well as steps and action stages (Angheluta, 2017).

Based on the SWOT analysis of the vocational education and training system, the Strategy for vocational education and training in Romania for the period 2016-2020, highlights some main aspects, among which, the relevance of VET systems in relation to the labour market requirements. In point $b$ ) highlights the fact that mechanisms have been developed to anticipate the skills required by the labour market and strategic planning at various levels, but these are only applicable in the initial vocational training; also, the responsible institutions do not have all the resources necessary for integrated management of the databases that would underpin the anticipation of the vocational training needs (Education Strategy of Romania 2016-2020, p. 15). Most countries make efforts as well as some progress towards establishing a system for anticipating skills in the labour market. The Republic of Moldova is still at the beginning of this process, where it participates in various seminars, conferences, workshops held in the Netherlands (Maastricht), Lithuania, Romania, Austria (Vienna), Italy (Turin), Georgia (Tbilisi), the Czech Republic (Prague), actions directed towards building capacity and exchange of experience in order to develop strategies, as well as institutional development of aspects regarding the skill anticipation, application of results within the analysis and elaboration of policies in the field of human resources development (Report, 2017, pages 25-27).

Anticipation of skills in educational programs depends on the analysis of how labour markets develop and, consequently, leading to changes in the way jobs, skills and learning needs develop. An effective anticipation and matching of skills, based on the data on the labour market and high quality skills, can link education, vocational training and employment.

Since the end of the 19th century J. Dewey, proposed objectives based on which the skills of tomorrow's generations could be developed and trained in the future, these are:

- to continue the education, developing the capacity for continuous growth; 


\section{International Journal of Social Science and Economic Research}

ISSN: $2455-8834$

Volume:05, Issue:08 "August 2020"

- to predict the consequences of their act, the result of this act by those with more experience, it is impossible for them to guide their activity smartly (Dewey, 1977, p. 25).

Even if the members of a generation do not share exactly the same values and beliefs, they share about the same learning experiences and thus contribute to the creation of a generational identity (Manolescu, 2020).

Strauss and Howe define a social generation as an aggregate of all people born over a period of approximately twenty years or throughout a phase of life: childhood, young adult, midlife, elderhood (Strauss and Howe, wikipedia).

If we look at the moment when a generation appears, the starting point is the period in which those who belong to it are born: the events of the respective period, the economic and technological evolution, the social balance make their mark in their development.

The Silents Generation grew up in an era where physical work was more important than knowledge-based work. It appreciates conformity, rules and duties and feels uncomfortable with ambiguity and change (Manolescu, 2020).

The Baby Boomers Generation understands the importance of technology both at home and at work, but it is still a challenge for some of them, sometimes longing for times when everyone was equal (Manolescu, 2020).

Generation $X$ is far more informed than the previous generations and expects employers to provide the latest technologies to help them in their work. They feel comfortable with the change; they are accustomed to an alert rhythm and changes around them. They work well in multicultural systems; accept religious, political, social diversity.

Generation $Y$ grew up in an environment full of easily accessible information and feels most comfortable with technology that has offered them a competitive advantage, sometimes they take up consulting adults in order to help them get used to using the technology. They tend to think fast and juggle more tasks at the same time. They use their technological intelligence for communication, learning or for fun. They grew up with a high dependence on technology and it negatively affects their ability to write or speak correctly (Manolescu, 2020).

At the global level, due to the high mobility, they keep pace with the changes, they are not affected by the political or economic instability in the world.

It is shown that, although generations $\mathrm{X}$ and $\mathrm{Y}$ are linked by bending towards technology, there are many other aspects that differentiate them, so that at certain times, reactions could be significantly different and require different approaches. On the other hand, the characteristics of the generations do not mean that all those born during the same period have the same manifestations or needs.

We live in a world that is changing with an overwhelming speed and the challenge we are facing right now, from the point of view of human resources, is the management of the four major categories of employees: baby boomers, generation X, generation $\mathrm{Y}$ and generation $\mathrm{Z}$. 


\section{International Journal of Social Science and Economic Research}

ISSN: $2455-8834$

Volume:05, Issue:08 "August 2020"

Generation $\mathbf{Z}$ includes young people who have just entered the labour market, whilst the Millennials-Y generation includesthose aged up to 29. Generation Xincludes those aged between 35 and almost 50 (Generations X, Y and Z, 2020).

Each generation can be assigned a type of thinking or approach on some key topics, and the common denominator comes from the economic, political and social context in which the members of a group have developed.

Starting from the understanding of education as a whole, as a global experience in terms of cognitive, practical, personal and social aspects, the directions of educational development have advanced, where the need for the development of a prospective personality is being observed, a personality prepared to anticipate short and long-term consequences, new situations, whereas anticipationrepresents a necessity of the modern individual to beable to find concrete and fast solutions in solving the multiple problems that appear in daily life (anticipating changes, risks and consequences).

In this respect, the Adult Education Platform in Europe (Angheluta, 2017) emphasizes an effective anticipation and matching of skills, based on data on the labour market and high quality skills, which can link education, vocational training and employment. This approach can encourage partnerships and cooperation to provide relevant VET skills and qualifications for jobs and, at the same time, followed by employers.

Deepening the problem and probability in the contemporary economic, social, political and cultural structure that determines the need for performance and quality in all areas, generates risks and a special receptivity of the given problems. The risk, through its economic, technical, social, pedagogical and psychological aspects, is presented as a determinant of the development pace, this approach is found in the communications of several managers of the 20th century (Vorobiev, 1991, p. 131).

When the essence of the risk is unknown, the human resource does not participate in decisionmaking and does not have the power to decide. Thus, the relation between anticipation and risk is observed, which is explained by the orientation towards the future, confirmed by the identification of the uncertainties (risks), by the anticipation of the potential consequences of the actions and of their probabilities.

The risk is defined as a situation, an event, which has not yet occured, but which may occur in the future, in which case, obtaining previously fixed results is threatened or enhanced. Thus, the risk can be either a threat or an opportunity and must be addressed as a combination of probability and impact (Risk Management, 2020).

Predicting or anticipating the future of the organization is part of strategic management, which comes as a response to the increase of uncertainty, risk and complexity of the environment in which it operates (Strategic anticipation, 2019). Risk anticipation is a step that takes place from the subjective assessment to the quantitative evaluation of risks. With the help of the tools 
offered by probability theory and statistics, it is possible to predict the size of future losses and the probability of their occurrence, thus being able to prioritize the risks according to their impact on the organization / individual and effectively allocate the resources needed to prevent them.

Avoidance of a stagnation situation is determined by raising the education to "achieve an indivudual capable of "predictingfor the sake of preventing", capable of triggering positive change both within oneself and outside" (Cojocariu, 2003, p. 27). The change can be conceived as a permanent reconstruction of the future existence and experience, which makes it the man of the third millennium able to to highly comply with social expectations in terms of cultural renewal and enrichment.

Therefore, education must prepare the individual capable of mastering the changes and accelerating the global development, whereas education must be designed in advance.

\section{Prospectiv vision. Research result}

It is known that the anticipatory planning was lauched in the technical field, therefore we have assumed the hypothesis that the students from theUniversity have formed the competence of anticipation. In order to verify this hypothesis, the questionnaire "Prospective vision" has been applied among students from the IT specialty.

To the question: Do you think your future specialty will be needed in the future? $88.10 \%$ of the respondents answered positivelygiving logical arguments in favour of the need for their profession.

\section{Figure 1.Anticipation of specialities in the future}

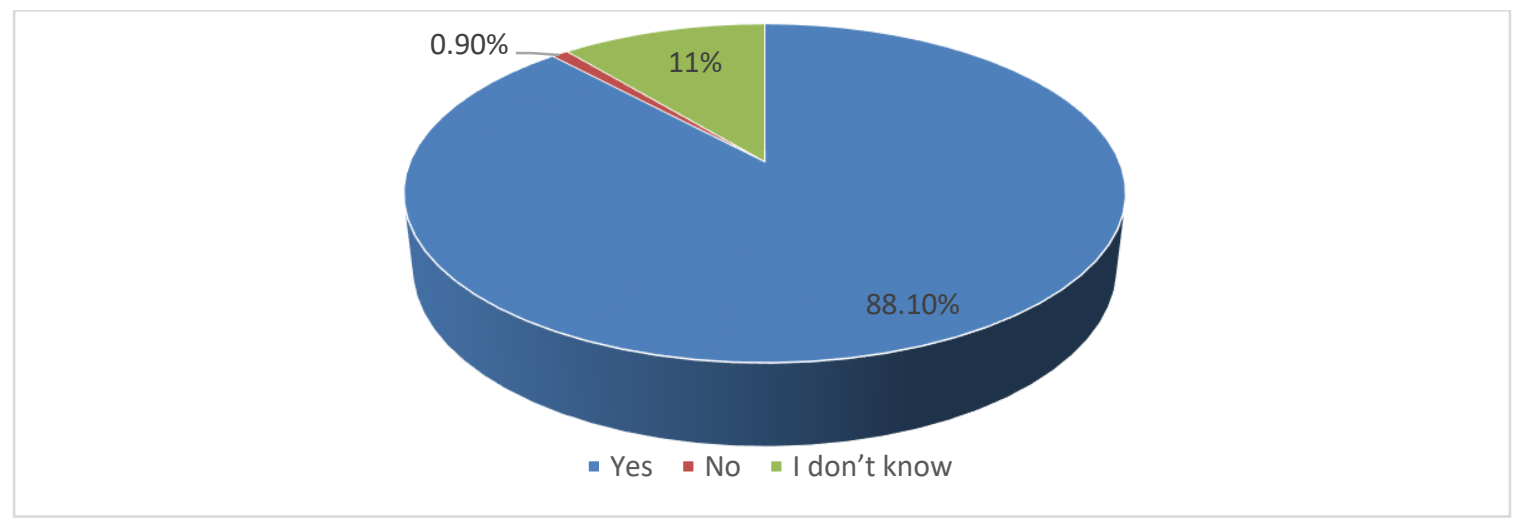

Source: Elaborated by author based on research 
From figure No. 1 we can observe that the majority of students anticipate their specialty to be one of the future, and $11 \%$ have selected the option ,they don't know”.

Another question addressed wasrelated to the type of actions takenwhich would lead toan appropriate adaptation to social changes, $30 \%$ of the respondents mentioned the participation in exchange programs, followed by $28 \%$ mentioning employment, the results are presented in the figure below:

\section{Figure 2. The frequency of actions leading to an appropriate adaptationto social changes}

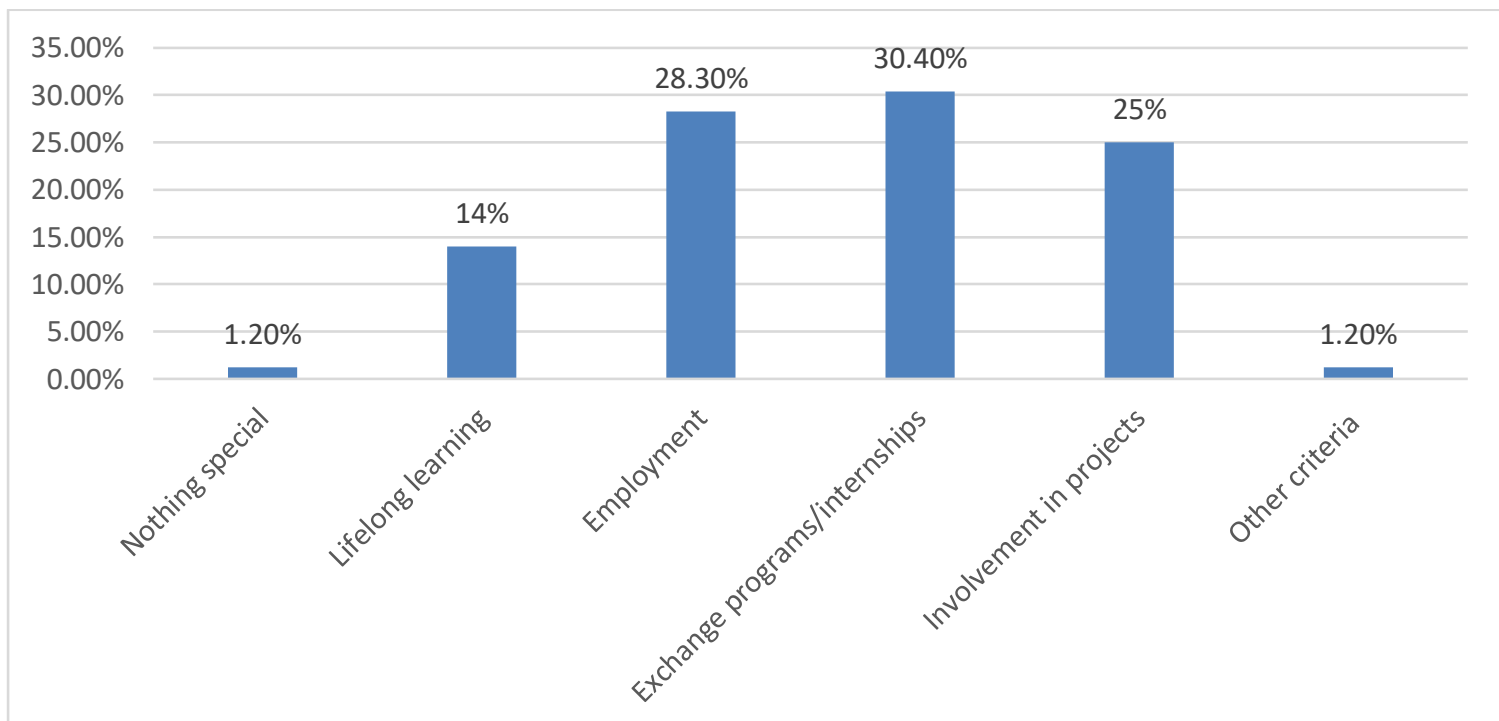

Source: Elaborated by author based on research

Participating in various exchange programs or in different projects presents an alternative to learning. Important for us is the vision of the $14 \%$ of students who opted for continuing education, thus highlighting the need for lifelong learning.

To verify the correctness of the answer to the item above weincluded an alternative item: If you knew that in the nearest future the labour market would not demand for your speciality-related, what measures would you take? Being an open-ended question the majority answered that they were ready to take re-training or lifelong training. These answers confirm our hypothesis that: students from the Technical University identify solutions to adapt to changes that may be in their specialty, thus highlighting the presence of elements of anticipation competence. These results confirm the hypothesis because IT students are very well informed about innovation and for this it is necessary to anticipate and orient towards change and adaptation. 


\section{International Journal of Social Science and Economic Research}

ISSN: $2455-8834$

Volume:05, Issue:08 "August 2020"

\section{Conclusions}

These results are positive considering the idea that, depending on the accelerated pace of changes, it is believed that adaptability is needed in the future.

We agree with the vision of the researcher Venera-Mihaela Cojocariu, who considers that the skill of adaptation is not as important as the one of anticipating the meaning and the rhythm of the changes, of elaborating the possible future, of articulating the perennial values, the background of these transformations and, above all, the development of the human being by cultivating humanity, dignity and responsibility (Cojocariu, 2003, p. 17). Also in this context, J. Botkin considers that the anticipattionskill includes the responsibility inherent in the influence and possible control of future events, therefore it can be considered one of the prospective skills (Botchin, Elmangjra and Malita, 1981, p. 51).

Although, it is very imortant to anticipate and predict the changes that occur in one area or another within a company, it is necessary to intervene in their flow to cause the desirable effects, or to avoid the undesirable ones, in terms of avoiding the risks.

Raising the education to "achieve an individual capable of "predicting for the sake of preventing", capable of triggering positive change both within oneself and outside" (Cojocariu, 2003, p. 27) fosters avoidance of stagnation.

The anticipattion skill as a finality, is a necessity of the contemporary personality(all generations) to identify solutions and solve problems: anticipating changes, risks and consequences.

In conclusion, we confirm that anticipation is a skill that faces different challenges, competition, adaptation to change, planning and innovation, but needs to become an intellectual property of individuals from the Republic of Moldova as well as from other countries, of the 21st century generation.

1. Anticipation is a phenomenon that can provide the subject with an opportunity to "look into the future". The concept combines the manifestations of mental abilities (anticipatory reflection) with the ability to act and make different decisions regarding the expected events in the future.

2. Anticipationrepresents a necessity of the modern individual to able to find concrete and fast solutions in solving the multiple problems that appear in daily life (anticipating changes, risks and consequences).

3. Both anticipation and planning foresee an end point of an act by preparing for future actions. At the same time, anticipation is the incipient phase of planning in the decision-making process by which we analyze the present (current situation), define the desired future (where we want to reach) and find the solutions to reach there.

4. Anticipation of skills is accomplished differently being based on the analysis of how labour markets develop and, consequently, leading to changes in the way skills and learning needs 


\section{International Journal of Social Science and Economic Research}

ISSN: $2455-8834$

Volume:05, Issue:08 "August 2020"

develop. In this regard, for many countries (the Netherlands, the UK, etc.) the skill anticipation is part of a political objective of creating a system of skill training needed for the labour market, whilst employers and educational beneficiaries decide on the skills they need, viathe given information. An effective skill anticipation, based on labour market data and high quality skills, can "link" education, vocational training and employment.

5. Anticipationrepresents a necessity of the modern individual toable to find specific and fast solutions in solving the multiple problems that appear in daily life (anticipating changes, risks and consequences). The development of anticipation skills is necessary for all generations, both $\mathrm{Z}$ (young people who are just entering the labor market) and those in the Millennials-Y generation (those up to 29 years old) and those in Generation $X$ (ages between 35 and almost 50 years). But our research has shown that it is easy for generations $\mathrm{Z}$ and $\mathrm{Y}$ to adapt to change, also to anticipate it. Research needs to be done to identify the reaction of people in generation $X$.

\section{References}

Angeluţă S., Anticiparea competențelor: privire spre viitor. (2017), EPALE (seen at 05.06.2019)https://epale.ec.europa.eu/ro/node/42244

Anticiparea strategica - previziunea oportunitatilor, strategia si previziuneahttp://www.qdidactic. com/bani-cariera/management/anticiparea-strategica-previziunea-oportunitatilor-s 573. php (seen at 12.12.2019)

Anticiparea http://ro.housepsych.com/antitsipatsiya default.htm (văzut 12.10.2019)

Barbaros C. (2018), Abordări teoretice privind definirea conceptului de competență. În: Univers Pedagogic . Revista științifică de pedagogie și psihologie a Institutului de Ştiințe ale Educației. nr.4 (60), p.19 - 25.

Botkin J., Elmandjra M., Maliţa M. (1981), Orizontul fără limite ale învăţării - lichidarea decalajului uman. Bucureşti: Ed. Politică. - 423 p.

Cojocariu V.-M., (2003) Educaţie pentru schimbare şi creativitate. Bucureşti: Ed. Didactică şi Pedagogică. 312 p.

Dewey J. (1977), Trei scrieri despre educaţie. Bucureşti: Ed. Didactică şi Pedagogică. 287 p.

Godet M. (1994), From anticipationto action. A handbook ofstratégic prospective. Paris: Publishing Dunod. 275 p. 


\section{International Journal of Social Science and Economic Research}

ISSN: $2455-8834$

Volume:05, Issue:08 "August 2020"

Generatiile X, Y si Z la locul de munca http://www.mantis.md/ro/blog/generatiile-X-y-si-z-lalocul- de-munca/ (văzut 02.02.2020)

Gremalchi A. (2015), Educaţie pentru o societate a cunoaşterii: Cadrul de referinţă al noului Curriculum naţional Studii de politici educaţionale. Institutul de Politici Publice, Tipografia Lexon-Prim Chișinău. 88 p

Landshere, G. (1979), Definirea obiectivelor educaţiei. București: EDP;

Manolescu R. Provocarea generațiilor. https://www.raresmanolescu.ro/provocarea-generatiilor-1/ (seen at 02.02 .2020 )

Panico V. Gubin S., Panico D., Munteanu T., (2011), Conceptul și modelul educaţiei pentru schimbare și dezvoltare a elevilor de vârstă școlară mică. Chișinău: UST.

Raport de activitate pentru anul 2016 (2017) APROBAT prin Hotărârea Consiliului de administraţie al Agenţiei Naţionale nr. 2 din. 22.03.2017 ANOFM - 33 p.

Managementul riscului silvic.usv.ro > cursuri > managementul_riscului (seen at 12.01.2020)

Stanciu M. (1999), Reforma conţinuturilor învăţământului. Cadru metodologic. Iaşi: Polirom247p.

Stânea R. Tehnici de comunicare eficientă. Suport de curs. http://www.incluziunesociala. ro/upls/31_49743_suport_curs_Tehnici_comunicare.pdf (văzut 02.02.2020)

Strategia educaţiei şi formării profesionale din România pentru perioada 2016-2020 https://www.edu.ro/sites/default/files/ fi\%C8\%99iere/Minister/2016/strategii/Strategia VE T\%2027\%2004\%202016.pdf;

Strauss and Howe. Teoria generaţiilor https://ro.wikipedia.org/wiki/Teoria_generatiilor_Strauss $\%$ E2\%80\%93Howe (vazut 02.02.2020)

Tarnovschi A., Racu J. (2017), Psihologia proceselor cognitive. Note de curs. Chișinău. - 217 p.

TownsendA. (2012), Dying careers and thriving careers: The jobs of tomorrow SNN august 13, 2012 (vizualizat 03.09.2018) https://edition.cnn.com/2012/08/13/opinion/careerstomorrow-town send/ index.html 
International Journal of Social Science and Economic Research

ISSN: 2455-8834

Volume:05, Issue:08 "August 2020"

Vasilache A., Bunyan D. Ghid de planificare strategică pentru dezvoltare socioeconomică locală bazată pe principiile egalităţii de gen şi ale drepturilor omului. - 59 p.http://descentralizare.gov.md/public/publications/942268_md_strategic_plann.pdf

Văideanu G., (1988), Educaţia la frontiera dintre milenii, Bucureşti: EDP. 318 p.

Воробьев Г.(1991), Школа будущего начинается сегодня, Москва: Просвещение. 237 с.

Стефановская Т. (1998), Педагогика: Наука и искусство, учебное пособие, Москва: Изд-во «Совершенство. 368 с. 